\title{
FAKTOR YANG BERHUBUNGAN DENGAN KEJADIAN BAYI BERAT LAHIR RENDAH (BBLR) DI RUANG PERINATOLOGI RSUD DRAJAT PRAWIRANEGARA
}

\author{
Factors related to Low Birth Weight (LBW) in the Perinatology Room \\ Drajat Prawiranegara Regional Hospital
}

\author{
Hanum Sasmita ${ }^{1}$, Husnul Khotimah ${ }^{2}$ \\ ${ }^{1}$ Poltekkes Kemenkes Palu \\ ${ }^{2}$ Universitas Faletehan \\ (husnulmehu@gmail.com)
}

\begin{abstract}
ABSTRAK
Salah satu faktor yang mempengaruhi kematian perinatal adalah Berat Bayi Lahir Rendah (BBLR). Angka BBLR di Provinsi Banten yaitu 9,7-10\% dan menduduki peringkat ke-15 di Indonesia. Studi ini bertujuan untuk mengetahui hubungan antara usia kehamilan, paritas dan preeklampsia dengan kejadian BBLR di ruang perinatologi Rumah Sakit Umum Daerah (RSUD) Drajat Prawiranegara. Desain penelitian adalah analitik observasional dengan pendekatan case control. Analisis data bivariat menggunakan chi square dan multivariat menggunakan regresi logistik berganda. Jumlah sampel kasus sebanyak 26 bayi dan kontrol (1:1) sebanyan 26 bayi sehingga total sampel sebanyak 52 bayi. Hasil penelitian yaitu terdapat hubungan yang bermakna antara usia kehamilan $(\mathrm{p}=0,060)$, paritas $(\mathrm{p}=0,038)$, dan preeklampsia $(\mathrm{P}=0,007)$ dengan kejadian BBLR. Faktor dominan yang berpengaruh terhadap kejadian BBLR adalah preeklampsi dengan nilai Odds Ratio (OR) variabel preeklampsia adalah 8,6, artinya preeklampsia memiliki peluang hampir 9 kali lebih besar menyebabkan bayi mengalami BBLR dibandingkan dengan tidak preeklampsia. Diharapkan kepada tenaga kesehatan dan RSUD Drajat Prawiranegara dapat memberikan penanganan dan tindakan yang tepat untuk mengatasi komplikasi dan penyulit yang berhubungan dengan berat bayi lahir rendah.
\end{abstract}

Kata kunci: Berat Bayi Lahir Rendah; usia kehamilan; jumlah anak; preeklampsia

\begin{abstract}
The incidence of $L B W$ is one of the factors that cause perinatal death. $L B W$ incidents in Banten Province occurred as much as 9.7-10\% and was ranked 15th in Indonesia. This study aims to determine the relationship between gestational age, parity and preeclampsia with the incidence of $L B W$ in the perinatology room of the Drajat Prawiranegara Regional General Hospital. The research design was observational analytic with case control approach. Bivariate data analysis uses chi square and multivariate uses multiple logistic regression. The number of case samples were 26 babies and control (1:1) of 26 babies so that the total sample was 52 babies. The results of the study are that there is a significant relationship between gestational age $(p=0.060)$, parity $(p=0.038)$, and preeclampsia ( $p=0.007)$ with $L B W$ incidence. The dominant factor influencing $L B W$ incidence is preeclampsia with an Odds Ratio $(O R)$ variable of preeclampsia is 8.6, meaning that preeclampsia has a nearly 9 times greater chance of causing a baby to experience LBW compared to non-preeclampsia. It is recommended to health workers and Drajat Prawiranegara Regional Hospital, to provide services, care, and appropriate actions to overcome complications and problems related to LBW incidence.
\end{abstract}

Keyword: LBW; gestational age; parity; preeclampsia

https://doi.org/10.33860/jik.v14i2.136

(C) 2020 by the authors. Submitted for possible open access publication under the terms and conditions of the Creative Commons Attribution (CC BY SA) license (https://creativecommons.org/licenses/by-sa/4.0/). 


\section{PENDAHULUAN}

Di Indonesia kurva angka mortalitas bayi menunjukkan penurunan dari tahun ke tahun. Meskipun demikian, pemerintah terus melakukan berbagai upaya untuk menekan Angka Kematian Bayi (AKB). Menurut hasil Survei Demografi dan Kesehatan Indonesia (SDKI) pada tahun 1991 jumlah kematian bayi 68 per 1000 kelahiran hidup dan menurun pada tahun 2017 dimana angka kematian 24 per 1000 kelahiran hidup. ${ }^{1}$

Tahun 2016 angka mortalitas neonatus di Provinsi Banten berjumlah 874per 1.000 kelahiran hidup dimana Kabupaten Serang menjadi salah satu daerah yang AKB nya masih tinggi dengan rasio yaitu 141 per 1.000 kelahiran hidup. Penyebab kematian perinatal diantaranya adalah berat bayi lahir rendah (BBLR). Angka kejadian BBLR di Provinsi Banten masih cukup tinggi diantara Provinsi lain yang ada di Inonesia dengan menempati posisi ke 15 dengan kasus sebesar 9,7$10 \% .^{2}$

Berdasarkan data di RSUD Drajat Prawiranegara Kabupaten Serang Provinsi Banten pada tahun 2019, kasus BBLR merupakan kasus tertinggi yaitu sebanyak 553 bayi dari total seluruh bayi yang mendapatkan penanganan di ruang perinatologi sebanyak 2764 bayi. $^{3}$

BBLR adalah berat badan bayi saat lahir adalah kurang dari 2500 gram dimana pengukuran berat badan dilakukan dalam periode waktu 1 jam setelah lahir tanpa memandang usia gestasi. ${ }^{4}$ Selain itu, terdapat pedoman lain untuk melakukan pengukuran BBLR yaitu Pedoman Pemantauan Wilayah Setempat (PWS) gizi. Menurut pedoman tersebut bayi dikatakan dalam kategori Berat Bayi Lahir Rendah jika bayi memiliki massa badan kurang dari 2500 gram saat 1-7 hari pasca dilahirkan. ${ }^{5}$

Beberapa dekade lalu hingga tahun 1961 penggunaan istilah BBLR merujuk kepada bayi prematur. Penggunaan istilah ini dirubah mengingat tidak hanya prematur yang menyebabkan bayi dengan berat badan lahir rendah. Terminologi bayi prematur (premature baby) dirubah oleh World Health Organization (WHO) menjadi berat bayi lahir rendah (low birth weight). Selain perubahan istilah, WHO juga merubah kriteri BBLR yang pada awalnya $\leq 2500$ gram menjadi < 2500 gram. ${ }^{5}$

Kondisi tubuh yang tidak stabil ketika bayi mengalami berat badan yang rendah saat dilahirkan dapat menimbulkanpeluang lebih besarterjadinya permasalahan pada berbagai sistem tubuh. Permasalahan tersebut antara lain gangguan pada metabolik, imunitas, pernapasan, peredaran darah, cairan dan elektrolit. ${ }^{6}$
Pencegahan kejadian BBLR sering mengalami kendala karena penyebab BBLR bersifat multifaktorial antara lain faktor ibu, janin, dan lingkungan. Usia ibu kurang dari 20 tahun atau lebih dari 35 tahun, terlalu dekatnya jarak kelahiran, penyulit dalam kehamilan (Anemia, Pendarahan Antepartum, Hipertensi, Preeklampsia, Ketuban pecah dini), keaadaan gizi yang kurang merupakan faktor-faktor dari sisi Ibu. Kelainan kromosom dan IUGR merupakan bagian dari faktor janin, dan kondisi sekitar yang mempengaruhi seperti paparan pancaran energi berbahaya dan zat yang mematikan lainnya. ${ }^{6}$

Bayi BBLR akan memiliki resiko delapan kali lebih besar untuk mengalami kematian daripada bayi yang normal. Semakin rendah berat badan bayi maka prognosis juga akan lebih buruk. Komplikasi neonatal seperti asfiksia, aspirasi pneumonia, perdarahan intracranial, infeksi, hipotermi dan hipoglikemia sering menjadi faktor penyebab kematian pada bayi. Angka kematian bayi termasuk di dalamnya kematian BBLR mencerminkan salah satu ukuran yang menggambarkan status kesehatan masyarakat. ${ }^{7}$

Ada beberapa hal yang mempengaruhi BBLR, diantaranya adalah apabila usia kehamilan ibu yang rendah (kurang dari normal) akan menyebabkan pertumbuhan janin yang terhambat dan akan berakibat terhadap berat badan bayi yang dilahirkan. Lepasnya plasenta lebih cepat merupakan salah satu penyebab umum bayi kurang bulan. Organ-organ tubuh bayi dengan gestasi yang kurang akan tidak berfungsi secara normal karena pertumbuhan nya yang belum optimal pada saat di dalm rahim sehingga bayi tersebut sangat rentan apabila hidup di luar rahim dan kemungkinan akan sulit untuk bertahan hidup. Semakin muda masa gestasi maka semakin kecil kemungkinan hidupnya. Selain itu bayi dengan berat lahir rendah ini akan mengalami komplikasi karena ketidaksempurnaan organ tubuhnya akibat usia kehamilan yang terlalu muda atau kurang. ${ }^{8}$

Paritas tinggi yaitu paritas lebih dari 3 atau lebih dari sama dengan 4 berhubungan dengan kejadian berat bayi lahir rendah dimana memiliki angka kematian ibu yang lebih besar. Semakin tinggi paritas, maka semakin tinggi juga kematian maternal. Kondisi jumlah melahirkan yang terlalu sering dapat menimbulkan gangguan rahim terutama dalam hal fisiologis vaskularisasi, sehingga mengganggu zat-zat gizi dapat masuk ke janin dan pada akhairnya akan melahirkan bayi dengan BBLR. Oleh sebab itu sebaiknya ibu melahirkan anak dibawah 4 orang. ${ }^{9}$

Kondisi preeklampsia pada ibu dapat meningkatkan resiko untuk melahirkan bayi BBLR dimana pada kondisi tersebut terjadi 
ketidaknormalan fungsi plasenta, kekejangan jaringan bahkan kerusakan pada jaringan itu sendiri. Hal tersebut mengakibatkan gagalnya proses masuknya trofoblas pada arteri spiralis sehingga akan menyebabkan terganggunya vaskularisasi uteroplasenter. Dengan menurunnya aliran darah dari uterus ke janin melalui plasenta tersebut akan mengakibatkan berkurangnya oksigen dalam jaringan dan kerusakan jaringan plasenta sehingga mempengaruhi sistem pertumbuhan organ-organ janin. Plasenta yang mengalami iskemia dan hipoksia akan menghasilkan radikal bebas berupa radikal hidroksil reaktif dan peroksida lipid yang akan beredar pada aliran darah sehingga dapat merusak membrane sel, nukleus dan protein sel endotel yang berakibat terhadap disfungsi endotel. ${ }^{10}$

Berdasarkan informasi di atas, maka tujuan dari penelitian ini adalah mengetahui analisis faktor apa saja yang mempengaruhi kejadian BBLR di Ruang Perinatologi RSUD Drajat Prawiranegara.

\section{METODE PENELITIAN}

Penelitian ini menggunakan design analitik dengan pendekatan case control. Sampel penelitian ini adalah 26 sampel kasus dan 26 sampel kontrol sehingga total sampel 52 bayi. Teknik pengambilan sampel yaitu kuota sampling. Pengumpulan data dilakukan dengan melihat dari buku register Ruang Perinatologi.

Variabel dependen penelitian ini adalah kejadian BBLR, sedangkan variabel independennya adalah usia kehamilan, paritas, dan preeklamsi.

Analisis data univariat dalam bentuk frekuensi, dilanjutkan dengan analisis bivariat dengan menggunakan chi square, dan multivariat dengan regresi logistik berganda.

\section{HASIL}

Dari tabel diatas didapatkan bahwa, terdapat setengahnya mengalami BBLR, lebih dari setengahnya usia kehamilan Preterm $(<37$ minggu), lebih dari setengahnya Paritas $<4$, dan lebih dari setengahnya mengalami preeklampsia

\section{Tabel 1. Distribusi frekuensi responden}

\begin{tabular}{lcc}
\hline Variabel & n & \% \\
\hline Kejadian BBLR & & \\
BBLR & 26 & 50 \\
Tidak BBLR & 26 & 50 \\
\hline
\end{tabular}

\begin{tabular}{llc}
\hline Variabel & n & \% \\
\hline UsiaKehamilan & & \\
$\quad$ Preterm $(<37$ minggu $)$ & 28 & 53,8 \\
$\quad$ Aterm $(\geq 37$ minggu) & 24 & 46,2 \\
Paritas & & \\
$\quad$ Paritas $\geq 4$ & 30 & 57,7 \\
$\quad$ Paritas $<4$ & 22 & 42,3 \\
Preeklampsia & & \\
$\quad$ Preeklampsia & 33 & 63,5 \\
$\quad$ Tidak Preeklampsia & 19 & 36,5 \\
\hline
\end{tabular}

Tabel 2 menunjukan bahwa kejadian BBLR proporsinya lebih besar terjadi pada usia kehamilan Preterm ( $<37$ minggu) yaitu $(67,9 \%)$ dibandingkan dengan usia kehamilan Aterm $(\geq 37$ minggu) $(29,2 \%)$. Pada variabel usia kehamilan, pengukuran hasil penelitian didapatkan Pvalue yaitu 0,060 yang menandakan bahwa ada hubungan yang bermakna antara usia kehamilan dengan kejadian BBLR dan didapatkan hasil OR 4,0 artinya usia kehamilan preterm ( $<37$ minggu) berisiko 4 kali lebih besar menyebabkan bayi mengalami BBLR dibandingkan dengan usia kehamilan Aterm ( $\geq 37$ minggu).

Berdasarkan hasil analisis data menunjukan bahwa kejadian BBLR proporsinya lebih besar terjadi pada ibu dengan Preeklampsia yaitu $(69,7 \%)$ dibandingkan dengan ibu yang tidak Preeklampsia $(15,8 \%)$. Pada variabel Pre Eklamsi, secara statistik diperoleh nilai $\mathrm{P}$ sebesar 0,007 $(\mathrm{P}<0,05)$ yang artinya BBLR memiliki keterkaitan dengan Preeklampsia dan didapatkan nilai OR 8,6 artinya Preeklampsia memiliki peluang 8,6 kali lebih besar menyebabkan bayi mengalami BBLR dibandingkan dengan tidak Preeklampsia.

Menurut pengukuran data analisis menunjukan bahwa kejadian BBLR proporsinya lebih besar terjadi pada Paritas $\geq 4$ yaitu $(66,7 \%)$ dibandingkan dengan Paritas <4 (27,3\%). Pada variabel Paritas, hasil uji statistik didapatkan nilai p sebesar 0,038 yang berarti bahwa secara statistik terdapat hubungan yang bermakna antara Paritas dengan kejadian BBLR. Didapatkan hasil OR 4,5 yang artinya Paritas $\geq 4$ memiliki peluang 4,5 kali lebih besar menyebabkan bayi mengalami BBLR dibandingkan dengan Paritas <4.

Penilaian analisis multivariat menandakan bahwaBBLR memiliki keterkaitan dengan Preeklampsia $(\mathrm{p}=0,007)$ dan usia kehamilan $(\mathrm{p}=0,038)$. Nilai $\operatorname{Exp}(\mathrm{B})$ memperlihatkan bahwa variabel yang paling berhubungan dengan BBLR adalah Preeklampsia 
Tabel 2. Faktor yang Berhubungan dengan BBLR

\begin{tabular}{|c|c|c|c|c|c|c|c|}
\hline \multirow{3}{*}{ Variabel } & \multicolumn{4}{|c|}{ Kejadian BBLR } & \multirow{3}{*}{ P Value* } & \multirow{3}{*}{$\mathbf{O R}^{*}$} & \multirow{3}{*}{$95 \% \mathrm{CI}^{*}$} \\
\hline & \multicolumn{2}{|c|}{ Kasus } & \multicolumn{2}{|c|}{ Kontrol } & & & \\
\hline & $\mathbf{n}$ & $\%$ & $\mathbf{n}$ & $\%$ & & & \\
\hline \multicolumn{8}{|l|}{ UsiaKehamilan } \\
\hline Preterm( $<37$ minggu $)$ & 19 & 67,9 & 9 & 32,1 & 0,060 & 4,0 & $0,9-16,8$ \\
\hline Aterm ( $\geq 37$ minggu $)$ & 7 & 29,2 & 17 & 70,8 & & & \\
\hline \multicolumn{8}{|l|}{ Paritas } \\
\hline Paritas $\geq 4$ & 20 & 66,7 & 10 & 33,3 & 0,038 & 4,5 & $1,1-18,4$ \\
\hline Paritas $<4$ & 6 & 27,3 & 16 & 72,7 & & & \\
\hline \multicolumn{8}{|l|}{$\overline{\text { Preeklampsia }}$} \\
\hline Preeklampsia & 23 & 69,7 & 10 & 30,3 & 0,007 & 8,6 & $1,8-41,3$ \\
\hline Tidak Preeklampsia & 3 & 15,8 & 16 & 84,2 & & & \\
\hline
\end{tabular}

\section{PEMBAHASAN}

1. Hubungan antara usia kehamilan dengan BBLR

Usia kehamilan adalah usia janin yang sesungguhnya yang mengacu pada panjang waktu kehamilan yang dihitung dari waktu pembuahan diukur dari hari pertama haid terakhir sampai waktunya melahirkan. ${ }^{11}$

Penelitian yang dilakukan oleh Septiani memiliki hasil yang sejalan dengan penelitian ini, bahwasanya ada hubungan yang bermakna antara usia kehamilan dengan kejadian BBLR di Wilayah Kerja Puskesmas Peudada Kabupaten Bireuen $(\mathrm{p}=0,012) .{ }^{9}$ Penelitian yang dilakukan oleh Saridewi juga mendukung penelitian ini yang menyebutkan bahwa ada ketrekaitan antara usia gestasi dengan BBLR di RSUD Cianjur $(\mathrm{p}=0,000) .{ }^{12}$

Begitu pun dengan hasil penelitian yang dilakukan oleh Sembiring yang membahas tentang keterkaitan antara BBLR dengan Usia Kehamilan, Usia, dan Paritas di Rumah Sakit Umum Mitra Medika Medan menyatakan hasil yang sama dengan penelitian ini bahwa secara statistik ada hubungan antara usia kehamilan dengan kejadian $\operatorname{BBLR}(\mathrm{p}=0,015) .{ }^{13}$

Usia kehamilan berhubungan dengan kejadian BBLR disebabkan karena kehamilan aterm yang diakibatkan oleh beberapa faktor seperti pre eklamsi, kekurangan energi kronik (KEK), riwayat sesak, insufisiensi plasenta, anemia sedang, plasenta previa, hidramnion dan ketuban pecah dini. Oleh karena faktor tersebut maka janin terlahir dalam kondisi BBLR walaupun usia kehamilannya aterm..$^{9,14}$

BBLR yang diakibatkan oleh usia gestasi yang cukup bulan (aterm) bisa disebabkan oleh kurangnya nutrisi saat hamil atau ibu hamil mengalami penyakit-penyakit lain sehingga pertumbuhan janin menjadi tidak optimal dan mengalami gangguan pertumbuhan. Dan pada usia gestasi kurang bulan (preterm) akan meningkatkan peluang BBLR dikarenakan adanya gangguan pertumbuhan janin sehingga mengakibatkan berat badan kurang. ${ }^{13}$

Menurut teori Back dan Rosenthal menyatakan bahwa berat badan bayi bertambah sesuai dengan usia gestasi. Hal ini dikarenakan pertumbuhan organ janin akan mengikuti sesuai dengan usia kehamilannya, semakin kurang usia kehamilannya maka akan semakin kurang sempurna pertumbuhan organnya termasuk berat lahirnya. ${ }^{15}$

Menurut asumsi peneliti, usia kehamilan berhubungan dengan BBLR, karena apabila usia kehamilan ibu cukup bulan maka pertumbuhan organ-organ janin akan berjalan dengan sempurnatermasuk berat badannya sehingga kemungkinan terjadinya BBLR akan kecil pada usia kehamilan aterm. Namun ada pula kondisi dimana usia kehamilan aterm masih terjadi BBLR dikarenakan adanya faktor riwayat penyakit yang diderita ibu sehingga mengganggu proses pertunbuhan dan perkembangan janin termasuk pula berat badannya akan menjadi kurang dari yang seharusnya.

2. Hubungan antara paritas dengan BBLR

Penelitian ini sejalan dengan penelitian yang dilakukan oleh Sembiring, Septiani, dan Khoiriyah yang menyatakan bahwa terdapat hubungan yang bermakna antara paritas dengan kejadian BBLR. ${ }^{9,13,16}$

Paritas adalah banyaknya jumlah anak yang dilahirkan. Menurut kesehatan, jumlah anak yang paling amanbagi seorang wanita adalah paritas kedua dan ketiga, sedangkan untuk paritas pertama dan lebih dari tiga dikatakan berisiko terhadap kehamilan, persalinan bahkan bagi bayi yang dilahirkan. Bagi ibu yang melahirkan untuk pertama kali akan mengalami penyulit karena ini merupakan pengalaman pertama baginya dan tidak mengetahui kondisi organ reproduksi nya tersebut apkah ada penyulit atau tidak. Sedangkan untuk 
paritas yang lebih tinggi yaitu paritas lebih dari tiga akan meningkatkan angka kematian maternal dan berisiko terjadinya kelainan pada perinatal diantaranya adalah bayi lahir cacat atau bayi lahir dalam keadaan berat badan yang rendah.Dan pada paritas yang lebih tinggi lagi yaitu $>4$ akan lebih berisiko karena ibu sudah mengalami penurunan fungsi organ reproduksi karena sebelumnya telah melahirkan beberapa kali sehingga akan menyebabkan terjadinya kelainan/gangguan pertumbuhan dan perkembangan janin termasuk diantaranya adalah BBLR. ${ }^{13}$

Salah satu faktor yang sering dikaitkan dengan BBLR adalah paritas. Semakin sering ibu melahirkan maka rahim akan semakin tipis dikarenakan lapisan dinding yang kaya akan nutrisi pada rahim telah dipakai untuk memberikan nutrisi pada janin saat kehamilan sehingga ketika terjadi kehamilan lagi maka nutrisi untuk janin akan berkurang dan mengakibatkan BBLR. Namun, hasil penelitian ini tidak sependapat dengan teori yang menyatakan bahwa paritas satu tidak aman, paritas 2-3 aman untuk hamil dan bersalin dan paritas lebih dari 3 tidak aman. Paritas lebih dari 5 menyebabkan berkurangnya kemampuan sistem organ reproduksi dalam bekerja sehingga akan berpengaruh terhadap kesehatan ibu dan bayinya, salah satunya adalah BBLR. ${ }^{4}$

Paritas lebih dari tiga akan menyebabkan resiko ibu melahirkan bayi dengan berat badan yang rendah. Hal ini disebabkan kondisi uterus yang semakin lemah karena berkurangnya fungsi organ-organ reproduksi dan sel-sel otot mulai berkurang fungsinya begitupula dengan bagian tubuh yang lainnya. Keseluruhan kondisi tersebut dapat menimbulkan dan memperbesar kemungkinan bayi mengalami BBLR. Selain itu, ibu yang sering melahirkan meningkatkan peluang terjadinya BBLR karena kemungkinan adanya kerusakan pada sistem kardiovaskuler dalam uterus yang akan mempengaruhi asupan nutrisi untuk janin pada saat kehamilan berikutnya, dan pada akhirnya akan mengakibatkan bayi mengalami BBLR. ${ }^{16}$

Kesimpulannya adalah paritas berkaitan dengan BBLR. Hal ini karena ketika ibu sering melahirkan maka dapat mengakibatkan terganggunya pemasukan gizi ke janin sehingga dapat mengakibatkan terjadinya bayi berat lahir rendah.

\section{Hubungan antara Preeklampsia dengan BBLR}

Penelitian ini sejalan dengan penelitian oleh Hartati dan Pradnyaningrum yang menyatakan bahwa terdapat hubungan yang bermakna antara Preeklampsia dengan kejadian BBLR. ${ }^{17,18}$
Preeklampsi pada ibu hamil akan meningkatkan peluang ibu bersalin dengan bayi berat lahir rendah. Ketika ibu mengalami preeklampsi maka tubuh akan mengalami ketidaknormalan fungsi plasenta dan pembuluh darah yang mengaliri janin dari plasenta mengalami kejang dan menjepit yang dapat menghambat aliran darah dari plasenta ke janinsehingga dapat menyebakan kerusakan jaringan endotelial. Pada saat ibu mengalami preeklampsia, tubuh ibu tidak dapat melakukan proses diferensiasi yang unik dari endomaternal pada kedua arteri spiralis sehingga proses regenerasi arteri spiralis tidak dapat dilakukan. Hal ini menyebabkan terjadinya pengurangan vaskularisasi uteroplasenta, sehingga jumlah molekul oksigen yang dialirkan ke plasenta berkurang dan menyebabkan kerusakan jaringan plasenta, ini berdampak pada terganggunag pertumbuhan janin dan terjadilah berat bayi lahir rendah. ${ }^{19}$

Kerusakan lapisan sel, nukleus dan protein sel endotel juga dapat terjadi akibat plasenta yang mengalami pengurangan pasokan oksigen dan kerusakan jaringan yang menyebabkan munculnya radikal bebas berupa radikal hidroksil reaktif dan peroksida lipid, sehingga akhirnya meninbulkan kerusakan dan ketidakberfungsian nya endotel. ${ }^{10}$

Jika preeklampsi yang dialami ibu parah maka akan menyebabkan bayi lahir dengan berat yang sangat rendah. Sebaliknya jika preeklampsi yang dialami ibu ringan maka akan menyebabkan bayi lahir yang tidak terlalu rendah. ${ }^{17}$

Kesimpulannya adalah berat bayi lahir rendah sangat dipengaruhi oleh preeklampsia pada ibu, karena adanya hambatan pada proses vaskularisasi uteroplasenter yang mengakibatkan vasospasme dan iskemi jaringan pada plasenta sehingga pemasukan zat-zat gizi dari plasenta ke janin akan berkurang, maka hal ini lah yang menyebabkan bayi lahir dengan berat badan yang kurang dari normal.

\section{SIMPULAN DAN SARAN}

Kesimpulan penelitian ini ada hubungan antara paritas, usia kehamilan dan preeklampsia dengan BBLR di Ruang Perinatologi RSUD Drajat Prawiranegara dan faktor dominan yang paling berpengaruh terhadap kejadian BBLR adalah Preeklampsia. Diharapkan kepada pihak pemberi layanan kesehatan dan pihak RSUD Drajat Prawiranegara, untuk melakukan penanganan dan tindakan yang tepat untuk mengatasi komplikasi dan masalah yang terkait dengan kejadian BBLR. 


\section{UCAPAN TERIMA KASIH}

Ucapan terima kasih kepada Rektor dan Ketua Lembaga Penelitian dan Pengembangan Masyarakat Universitas Faletehan yang telah banyak memberikan bantuan berupa dana, dukungan dan fasilitas dalam penyelesaian penelitian ini.

\section{DAFTAR PUSTAKA}

1. Kementerian Kesehatan R.I. Survey Demografi Kesehatan Indonesia tahun 2017. Jakarta: Kementerian Kesehatan R.I.; 2017.

2. Dinas Kesehatan Propinsi Banten. Profil Kesehatan Provinsi Banten tahun 2017. Tangerang: Dinas Kesehatan Propinsi Banten; 2018.

3. RSUD Drajat Prawiranegara. Buku Register Ruang Perinatologi tahun 2019. Tangerang; 2019.

4. Manuaba I, Bagus G. Ilmu Penyakit Kebidanan, Kandungan dan Pelayanan KB untuk pendidikan Bidan. EGC, Jakarta; 2007.

5. Putra WKY. Pengukuran antropometri pengganti untuk mendeteksi kasus BBLR di Kota Pontianak dan Kabupaten Kubu Raya tahun 2011. Universitas Indonesia; 2012.

6. Proverawati A, Ismawati C. BBLR (berat badan lahir rendah). Yogyakarta Nuha Med. 2010;61.

7. Amiruddin R. Determinan Kesehatan Ibu dan Anak. Jakarta: Trans Info Media; 2014.

8. Simarmata OS. Hubungan Kualitas Pelayanan Antenatal Terhadap Kejadian Bayi Berat Lahir Rendah di Indonesia (Analisis Data Sekunder Survei Demografi dan Kesehatan Indonesia 2007). 2010;

9. Septiani M, Ulfa M. Faktor-Faktor yang Berhubungan dengan Kejadian BBLR di Wilayah Kerja Puskesmas Peudada Kabupaten Bireuen. J Healthc Technol Med. 2018;4(2):258-75.

10. Wati LK. Hubungan antara Preeklampsia/Eklampsia dengan Kejadian Berat Badan Lahir Rendah (BBLR) Di RSUD Dokter
Soedarso Pontianak Tahun 2012. Tanjungpura University; 2012.

11. Marmi. Asuhan neonatus, bayi, balita dan anak pra sekolah. Yogyakarta: Pustaka Pelajar; 2012.

12. Saridewi W. Hubungan Umur Kehamilan dengan Kejadian Asfiksia dan BBLR DI RSUD Cianjur. J BIMTAS J Kebidanan Umtas. 2019;3(1):7-12.

13. Sembiring JB, Pratiwi D, Sarumaha A. Hubungan Usia, Paritas dan Usia Kehamilan dengan Bayi Berat Lahir Rendah di Rumah Sakit Umum Mitra Medika Medan. J Bidan Komunitas. 2019;2(1):38-46.

14. Widya Pani. Hubungan Kejadian Bayi Berat Lahir Rendah dengan Riwayat Ibu Hamil Kekurangan Energi Kronis di Wilayah Puskesmas Pantoloan. J Bidan Cerdas [Internet]. 29 April 2018;1(1):21-6. Tersedia pada:

http://jurnal.poltekkespalu.ac.id/index.php/JBC /article/view/49

15. Jayanti FA, Dharmawan Y, Aruben R. Faktorfaktor yang berhubungan dengan kejadian berat badan lahir rendah di wilayah kerja puskesmas bangetayu kota Semarang tahun 2016. J Kesehat Masy. 2017;5(4):812-22.

16. Khoiriah A. Hubungan Antara Usia dan Paritas Ibu Bersalin dengan Bayi Berat Lahir Rendah (BBLR) di Rumah Sakit Islam Siti Khadijah Palembang. J Kesehat. 2017;8(2):310-4.

17. Hartati N. Preeklampsia dengan Berat Badan Lahir Rendah (BBLR) pada ibu bersalin. J Gema Keperawatan. 2018;11(1).

18. Hartati NN, Surinati IDAK, Pradnyaningrum NNDV. Hubungan Preeklampsia dengan Berat Badan Lahir Rendah (BBLR) pada Ibu Bersalin di RSUD Wangaya. J Gema Keperawatan [Internet]. 2018;11(1):1-9. Tersedia pada: http://ejournal.poltekkes-

denpasar.ac.id/index.php/JGK/article/download /271/113

19. Prawirohardjo S. Obstetrics (Ilmu Kebidanan). Jakarta PT Bina Pustaka Sarwono Prawirohardjo. 2009; 